\title{
Surto de carbúnculo sintomático em bezerros
}

\author{
Outbreak of black leg in calves
}

\author{
Ronnie Antunes de Assis ${ }^{1}$ Elias Jorge Facury Filho ${ }^{2}$ \\ Francisco Carlos Faria Lobato ${ }^{3}$ Antônio Último de Carvalho ${ }^{2}$ \\ Paulo Marcos Ferreira ${ }^{2}$ Augusto Vinícius Arruda de Carvalho ${ }^{4}$
}

\section{-NOTA -}

\section{RESUMO}

Este relato descreve um surto de carbúnculo sintomático em Nova União, Minas Gerais, Brasil, com ênfase no uso de diferentes técnicas laboratoriais. Clostridium chauvoei foi isolado em cultura pura, bem como detectado por uma técnica de imunofluorescência direta (IFD) e por uma técnica de reação em cadeia da polimerase (PCR) a partir de cultura pura obtida do tecido muscular esquelético lesado de um animal necropsiado.

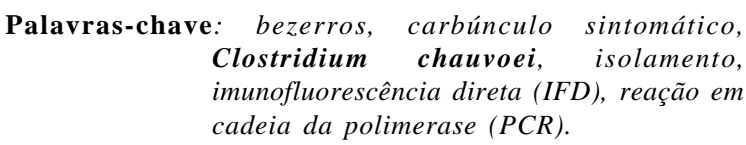

\section{ABSTRACT}

This report describes an outbreak of black leg in calves in Nova União, Minas Gerais, Brazil, with emphasis in the use of different laboratorial techniques. Clostridium chauvoei was isolated in pure culture, and detected by a fluorescent antibody technique (FAT) and by a polymerase chain reaction (PCR) technique from pure culture obtained from affected skeletal muscle of one animal.

Key words: calves, black leg, Clostridium chauvoei, isolation, fluorescent antibody technique (FAT), polymerase chain reaction $(P C R)$.

Carbúnculo sintomático e edema maligno compreendem o grupo das mionecroses, clostridioses altamente fatais causadas por bactérias anaeróbicas do gênero Clostridium, que afetam o tecido muscular e subcutâneo de ruminantes e outras espécies animais (STERNE \& BATTY, 1975). Em bovinos, o carbúnculo sintomático é uma infecção "endógena" não contagiosa produzida pelo Clostridium chauvoei. Em contraste, o edema maligno nas diferentes espécies animais susceptíveis, é uma doença “exógena”, relacionada com a presença de feridas na pele, podendo ser causada pelo C. chauvoei, Clostridium septicum, Clostridium sordellii, Clostridium novyi tipo A e Clostridium perfringens tipo A (GYLES, 1993). Existem duas formas de manifestação do carbúnculo sintomático nos bovinos. A forma clássica, de ocorrência mais freqüente e que afeta principalmente a musculatura esquelética, e a visceral, raramente encontrada, afetando principalmente o coração (UZAL et al., 2003a). Essa forma ainda não foi relatada no país. A real patogenia do carbúnculo sintomático em bovinos, tanto o clássico como o visceral, é ainda incerta. Na forma clássica, a hipótese corrente é que os esporos presentes no intestino são veiculados por macrófagos até musculatura onde permanecem em latência. Traumas nas grandes massas musculares, criam um ambiente de baixo potencial de óxido-redução, propiciando a germinação dos esporos e a conseqüiente produção de toxinas (GYLES, 1993).

\footnotetext{
${ }^{1}$ Escola de Veterinária, Universidade federal de Minas Gerais (UFMG), Laboratório de Anaeróbios. Avenida Antônio Carlos 6627, 30123-970, Pampulha, Belo Horizonte, MG, Brasil. E-mail: assisra@ rwnet.com.br. Autor para correspondência.

${ }^{2}$ Clínica de Ruminantes, Escola de Veterinária, UFMG, Belo Horizonte, MG, Brasil.

${ }^{3}$ Doenças Bacterianas, Escola de Veterinária, UFMG, Belo Horizonte, MG, Brasil.

${ }^{4}$ Laboratório Regional de Apoio Animal do Ministério da Agricultura, Pecuária e Abastecimento, LARA, MG, Pedro Leopoldo, MG, Brasil.
} 
C. chauvoei está amplamente distribuído no solo e trato intestinal dos herbívoros. A sobrevivência do agente no solo sob a forma de esporos é o fator mais significante para a transmissão aos bovinos, pois a ingestão de pastos contaminados com esporos constitui-se na principal fonte de infecção (GYLES, 1993). Bovinos jovens, entre quatro meses e três anos de idade no mais alto patamar nutricional são os mais susceptíveis. Clinicamente, os animais apresentam temperatura elevada, anorexia, depressão e manqueira quando o membro é atingido. $\mathrm{O}$ local torna-se edematoso e, à palpação, é observada crepitação decorrente das bolhas de gás produzidas pela multiplicação da bactéria. A evolução para morte ocorre geralmente em até 72 horas. A lesão é acompanhada por edema, hemorragia e necrose miofibrilar, exalando acentuado odor rançoso (HATEWAY, 1990). Em relação ao edema maligno nos bovinos, o mesmo apresenta sintomatologia clínica, curso e lesões macro e microscópicas semelhantes aos do carbúnculo sintomático clássico.Esta nota tem por objetivo descrever um surto de carbúnculo sintomático em bezerros com ênfase nas técnicas de imunofluorescência direta (IFD) e na reação em cadeia da polimerase (PCR), no município de Nova União, Minas Gerais, Brasil.

Em um lote de oito bezerros mestiços Girolandos de 4 a 8 meses de idade, com boa condição corporal, morreram três animais num período de 12 dias. Esses eram criados em regime extensivo, alojados em piquetes ricos em matéria orgânica adjacentes ao curral e nunca haviam sido vacinados contra clostridioses. Segundo informações do proprietário, os animais acometidos apresentaram manqueira, seguida de decúbito esternal, depressão e morreram entre 24 e 48 horas. Um animal foi encaminhado para o Hospital Veterinário da Escola de Veterinária da UFMG e foi submetido à necropsia aproximadamente três horas após a morte. Fragmento da musculatura lesada foi preservado em um recipiente contendo formol tamponado a $10 \%$ e encaminhado para a histologia rotineira de inclusão em parafina (LUNA, 1968). Secções de $5 \mu \mathrm{m}$ foram obtidas para a coloração de hematoxilina-eosina (LUNA, 1968). Fragmento adicional foi assepticamente coletado e submetido sob refrigeração ao Laboratório de Anaeróbios da Escola de Veterinária da UFMG, Belo Horizonte, Minas Gerais, Brasil. O mesmo foi assepticamente semeado em ágar sangue e incubado a $37^{\circ} \mathrm{C}$ em condições de aerobiose e anaerobiose por 48 horas. Impressões do tecido foram coradas pelo Gram e examinados por uma técnica de IFD como previamente descrito por ASSIS et al., (2001), usando conjugados anti-C. chauvoei, $\boldsymbol{C}$. septicum, $C$. sordellii, $C$. novyi tipo A e $C$. perfringens tipo A produzidos por ASSIS et al., (2001). Amostras de referência de $\boldsymbol{C}$. chauvoei (ATCC 10092), C. septicum (ATCC 12464), C. sordellii (ATCC 9764), C. novyi tipo A (ATCC 19402) e $\boldsymbol{C}$. perfringens tipo A (ATCC 3624), foram usadas como controle em cada preparação. Cultura pura obtida em atmosfera de anaerobiose foi processada por uma técnica de PCR para o gene que codifica a subunidade $16 \mathrm{~S}$ rRNA de $\boldsymbol{C}$. chauvoei conforme a metodologia descrita por UZAL et al (2003b). Para avaliar a especificidade dos iniciadores de $\boldsymbol{C}$. chauvoei, utilizaram-se extratos de DNA provenientes de amostras de referência de $\boldsymbol{C}$. septicum (ATCC 12464), C. sordellii (ATCC 9764), C. novyi tipo A(ATCC 19402) e $\boldsymbol{C}$. perfringens tipo A (ATCC 3624). Como controle positivo de C. chauvoei, foi utilizado extrato de DNA obtido da amostra ATCC 10092, e como controle negativo utilizaram-se os reagentes da PCR sem extratos de DNA.

À necropsia, observou-se tumefação das grandes massas musculares do membro posterior direito, com crepitação à palpação. Não existiam feridas cutâneas. Ao corte dessa região, verificouse presença de líquido sero-sanguinolento, musculatura de coloração vermelho enegrecida, com desorganização das fibras e aspecto de desvitalização. Não foi observada lesão cardíaca. $\mathrm{O}$ exame histopatológico revelou a presença de moderado infiltrado inflamatório de células mononucleares e focos de degeneração vacuolar e hialina das fibras musculares, que às vezes apresentaram-se fragmentadas e com perda da estriação. Estas alterações estavam associadas com extensas áreas de edema intersticial e hemorragia. Verificou-se ainda presença difusa de bastonetes basofílicos entre os feixes musculares. Observaramse nas impressões do tecido, bastonetes Gram positivos, pleomórficos, esporulados ou não, identificados como $\boldsymbol{C}$. chauvoei pela técnica de IFD. Cada amostra controle foi corada apenas pelo conjugado correspondente. Cultura pura de bastonetes Gram positivos com a mesma morfologia descrita acima foi obtida a partir do fragmento da musculatura lesada incubado em anaerobiose. $\boldsymbol{C}$. chauvoei foi também identificado pela PCR a partir do isolado, e nenhuma reação cruzada foi observada a partir dos extratos de DNA dos outros clostrídios (Figura1). Não houve crescimento em aerobiose.

Com base no histórico, sinais clínicos, achados de necropsia, histopatológicos e microbiológicos, permitiu-se firmar o diagnóstico de carbúnculo sintomático. IFD, em impressões obtidas diretamente do espécime clínico suspeito, é o critério considerado suficiente para o diagnóstico definitivo de mionecroses (STERNE \& BATTY, 1975). Além 


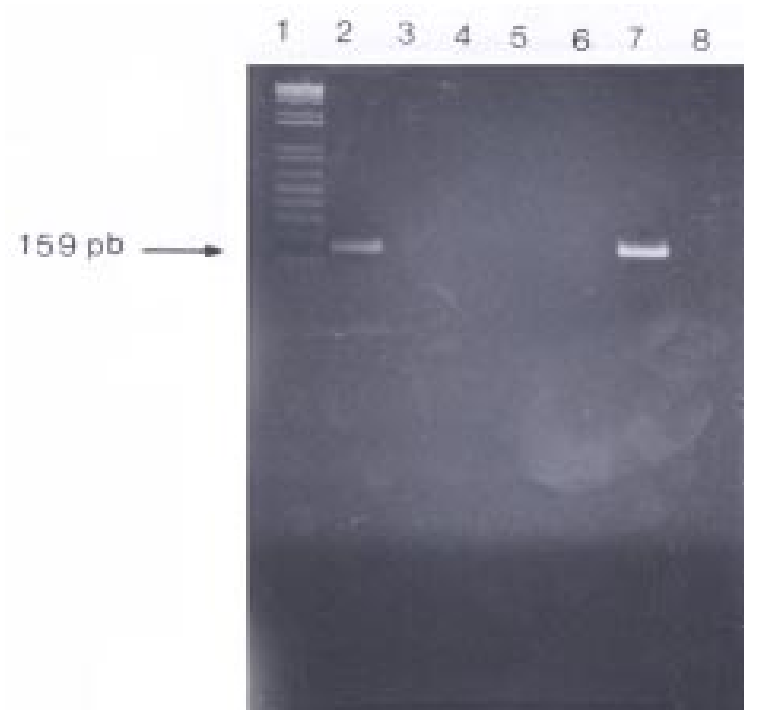

Figura 1 - Eletroforese em gel de agarose a $2 \%$. Canaleta 1. marcador de peso molecular $1 \mathrm{~kb}$ plus DNA Ladder (Invitrogen, Carlsbad, CA, EUA). Canaleta 2. Extrato de DNA de Clostridium chauvoei obtido a partir de cultura pura do tecido muscular esquelético lesado. Canaletas 3, 4, 5 e 6: extratos de DNA de amostras de referência de Clostridium septicum (ATCC 12464), Clostridium sordellii (ATCC 9714), Clostridium novyi tipo A (ATCC 19402) e Clostridium perfringens tipo A (ATCC 3624), respectivamente. Canaleta 7: controle positivo de C. chauvoei.(ATCC 10092) Canaleta 8: controle negativo.

disso, a técnica de PCR confirmou o diagnóstico de carbúnculo sintomático.

É provável que a ocorrência da doença nestes animais, foi relacionada à susceptibilidade dos hospedeiros em virtude da idade e ausência de imunidade pela falta de vacinação, aliados às condições ambientais em que viviam, e fatores relacionados ao manejo podem ter favorecido a contaminação e a posterior germinação dos esporos latentes na musculatura esquelética.

No Brasil, os trabalhos que até então reportaram o diagnóstico do carbúnculo sintomático e do edema maligno, basearam-se somente em dados clínicos, achados de necropsia e aspectos microbiológicos enfatizados apenas em caracteres morfológicos e provas bioquímicas (CORREA et al., 1980; BALDASSI et al., 1985). Entretanto, procedimentos bacteriológicos desta natureza, constituem-se na maioria das vezes, grandes entraves ao diagnóstico etiológico dessas enfermidades, pois C. chauvoei e $\boldsymbol{C}$. septicum, que são os agentes mais freqüentemente encontrados nos casos de mionecroses (BALDASSI et al., 1985), são difíceis de serem diferenciados em razão da similaridade dos caracteres morfológicos e reações bioquímicas (STERNE \& BATTY, 1975). Também, em meio sólido, $C$. septicum apresenta um crescimento rápido, inibindo o crescimento do C. chauvoei (KUHNERT et al., 1997), favorecendo a ocorrência de falsos positivos. Além disso, o isolamento desses agentes requer de quatro dias a uma semana para se completar (ASSIS et al., 2001). Em razão disto, técnicas como a IFD e PCR permitem um diagnóstico mais rápido e seguro do carbúnculo sintomático e do edema maligno. Com o emprego destas técnicas, é possível melhorar o diagnóstico, tornando possível determinar a real prevalência dos clostrídios envolvidos nos quadros dessas doenças no nosso meio e implementar medidas de controle por meio da imunização dos animais.

\section{AGRADECIMENTOS}

Os autores agradecem ao CNPq e ao Dr Eduardo Henrique Moreira Lima da Escola de Veterinária da UFMG pelo processamento fotográfico.

\section{REFERÊNCIAS}

ASSIS, R.A. et al. Producción y evaluación de conjugados fluorescentes para diagnóstico de mancha y gangrena gaseosa. Revista de Medicina Veterinária, v.82, n.2, p.68-70, 2001.

BALDASSI, L. et al. Observações sobre a incidência de gangrena gasosa e carbúnculo sintomático durante 10 anos, 1970-1979, no estado de São Paulo. O Biológico, v.51, n.6, p.161-165, 1985 .

CORREA, W.M. et al. Enfermidades por clostrídios 19681978 (clostridial diseases 1968-1978). Arquivo Brasileiro de Medicina Veterinária e Zootecnia, v.32, n.3, p.369-374, 1980 .

GYLES, C.L. Pathogenesis of bacterial infections in animals. In: GYLES, C.L.; THOEN, C.O. Histotoxic clostridia. 2.ed. Ames : Iowa University, 1993. p.106-113.

HATEWAY, C.L. Toxigenic clostridia. Clinical Microbiological Reviews, v.3, n.1, p.66-98, 1990.

KUHNERT, P. et al. Identification of Clostridium chauvoei in cultures and clinical material from blackleg using PCR. Veterinary Microbiology, v.57, n.2-3, p.291-298, 1997.

LUNA, L.G. Manual of the histologic staining methods of the armed forces institute of pathology. 3.ed. New York : McGraw Hill, 1968. 258p.

Sterne, M.; BATty, I. Pathogenic clostridia. London: Butterworths, 1975. 144p.

UZAL, F.A. et al. Outbreak of clostridial myocarditis in calves. Veterinary Record, v.152, n.5, p.134-136, 2003a.

UZAL, F.A. et al. PCR detection of Clostridium chauvoei in pure cultures and in formalin-fixed, paraffin-embedded tissues. Vet Microbiol, v.91, n.2-3, p.239-248, 2003 b. 